\title{
Review of Quantitative Finance and Accounting
}

Editor: Cheng-few Lee, Rutgers University, School of Business, New Brunswick, NJ

Associate Editors: R.P. Beatty, V. Bernard, J. Bicksler, P.P. Boyle, L.D. Brown, E. Burmeister, A.H. Chen, C. Chen, D.W. Collins, V. Errunza, W. Ferson, J.E. Finnerty, J.C. Francis, L.R. Glosten, C.J. Jacklin, B. Jaggi, F. C. Jen, K. John, R. Kihlstrom, E.H. Kim, S.J. Kon, R.A. Korajczyk, K. Lawrence, J.C. Lee, H. Levy, A.W. Lo, J.C. McKeown, L. Merville, P. Newbold, J. Ohlson, T. Petzel, M.A. Reinganum, J. Ronen, C. W. Sealey, L. W. Senbet, J. Shanken, L. Summers, R. J. Sweeney, S. Turnovsky, R.E. Verrecchia

Review of Quantitative Finance and Accounting deals with research involving the interaction of finance with accounting, economics and quantitative methods, focused on finance and accounting. The papers published present useful theoretical and methodological results with the support of interesting empirical applications. Purely theoretical and methodological research with the potential for important applications is also published. Besides the traditional high-quality, theoretical and empirical research in finance, the journal also publishes papers dealing with interdisciplinary topics including:

financial accounting which uses financial and economic theory and/or methodology; managerial accounting and auditing which use financial and economic theory and/or methodology to deal with internal accounting data and decision making; macro-economics which uses finance theory and/or methodology to analyze fiscal and/or monetary policies; managerial economics which uses financial theory and/or methodology to analyze the decisions of a firm.

The journal is abstracted in the International Current Awareness Services.

1993 Subscription Information ISSN 0924-865X

Volume 3 (4 issues) Subscription rate:Dfl.347.00/\$187.00

to order, or to request a sample copy, contact:

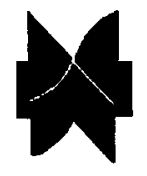

Kluwer Academic Publishers P.O. Box 358, Accord Station, Hingham, MA 02018 • phone (617) 871-6600 - $\operatorname{fax}(617) 871-6528$ • e-mail: kluwer@worid.std.com 


\section{Call for Papers and Participants \\ 1994 ANNUAL MEETINGS OF \\ THE WESTERN FINANCE ASSOCIATION \\ June 18-21, 1994 \\ Santa Fe, New Mexico}

Members and friends of the Western Finance Association are invited to submit papers to be considered for presentation at the 1994 Annual Meetings. Papers on any topic related to financial economics will be considered.

\section{Submission of Papers:}

Send four (4) copies of the paper to the Program Chairman no later than November 19, 1993. Each paper should include an abstract that will assist the program chairman in classifying it. Author names, affiliations and acknowledgments shall appear on a separate page at the beginning of the manuscript. Papers, absent author identification, will be reviewed by two members of the program committee. Authors will be notified of the program committee's decision regarding their paper in February, 1994. Multiple submissions by the same author or submission of papers presented at other major finance meetings reduce the chance of acceptance. Abstracts and papers accepted for publication should not be submitted.

\section{Submission Fee:}

A check for $\$ 20.00$ payable to the Western Finance Association should be included with each submitted paper. The fee will be used to help defray the cost of processing the paper.

\section{Submit to:}

Professor Milton Harris, Program Chairman, WFA Meetings, Graduate School of Business, University of Chicago, 1101 East 58th Street, Chicago, Illinois 60637. 


\section{Finance Association Meetings}

International Conference on Financial Markets Dynamics and Forecasting

Dates: September 2-4, 1993

Place: Paris, France

Deadline for program participation: June 1, 1993

Contact: Véronique Léon-Marois, Caisse des Dépôts et Consignations, Service des Études Économiques et Financiéres, 195 Boulevard Saint-Germain, 75007, Paris, France.

\section{Southern Finance Association}

Dates: November 17-20, 1993

Place: New Orleans, Louisiana

Deadline for program participation: February 10, 1993

Contact: Robert Schweitzer, University of Delaware, Department of Finance, Newark, Delaware 19716.

\section{Sixth Annual Australasian Finance and Banking Conference}

Dates: December 9-10, 1993

Place: Sydney, Australia

Deadline for program participation: July 16, 1993

Contact: Vic Edwards, School of Banking and Finance, University of New South Wales, P.O. Box 1, Kensington, N.S.W. 2033, Australia.

\section{Association of Managerial Economists}

Dates: January 3-5, 1994

Place: Boston, Massachusetts

Deadline for program participation: May 1, 1993

Contact: Mark Hirshey, University of Kansas, School of Business, Lawrence, Kansas 66045

\section{Southwestern Finance Association}

Dates: March 3-4, 1994

Place: Dallas, Texas

Deadline for program participation: September 1, 1993

Contact: William Reichenstein, Baylor University, Hankamer School of Business, Finance, Insurance and Real Estate Department, P.O. Box 98004, Waco, Texas 76798-8004.

\section{Eastern Finance Association}

Dates: April 13-16, 1994

Place: Boston, Massachusetts

Deadline for program participation: September 17, 1993

Contact: Joseph Finnerty, University of Illinois, Department of Finance, 1206 South Sixth Street, Champaign, Illinois 61820 .

\section{Western Social Science Association (Finance)}

Dates: April 20-23, 1994

Place: Albuquerque, New Mexico

Deadline for program participation: November 1, 1993

Contact: Kashi Nath Tiwari, Kennesaw State College, School of Business, Marietta, Georgia 30061.

\section{Western Finance Association}

Dates: June 18-21, 1994

Place: Santa Fe, New Mexico

Deadline for program participation: November 19, 1993

Contact: Mitton Harris, University of Chicago, Graduate School of Business, 1101 East 58th Street, Chicago, Illinois 60637. 


\section{JFQA Style Requirements}

Manuscripts must be submitted in quadruplicate with a cover page showing title, author name(s) and affiliation(s), and work phone number(s). The first page of text should begin with the title only. A short one-paragraph abstract of no more than 100 words must be included. Manuscripts must be typed double-spaced on one side of the page. Underline only words or phrases that are to be italicized; do not underline headings or subheadings, or use boldface type. All sections of the paper, beginning with the introduction and ending with a conclusion or summary, must be numbered with Roman numerals. Subsection headings must be lettered A, B, C, etc

The manuscript should explain its relation to other research in the field, especially recently published material. References cited in the text should be noted by the last name(s) of the author(s) followed by the publication year enclosed in parentheses without punctuation: Smith (1988). When a particular page, section, or equation is referred to, the reference also should be placed within parentheses: (Smith and Jones (1988), p. 222), (Green (1988a), eq. 3).

Lengthy mathematical proofs and extensive tables should be placed in an appendix or omitted from the manuscript entirely. In the latter case, the author may indicate in a footnote that proofs or tables are available on request. The author should make every effort to explain the meaning of mathematical proofs.

The author should check the manuscript for clarity, grammar, spelling, and punctuation in order to minimize the number of editorial changes and the necessity of expensive corrections at the proof stage. All abbreviations must be defined.

Equations. All but very short mathematical expressions should be displayed on a separate line and centered. Important displayed equations must be identified by consecutive Arabic numerals in parentheses on the left. Expressions should be aligned and subscripts and superscripts clearly marked to avoid confusion. Please differentiate between the letter I (ell), the numeral 1 (one), the letter o (oh), and the numeral 0 (zero) with marginal notes.

Tables. Each table must be titled and numbered consecutively with Arabic numerals. Please check the text to make sure there is a reference to each table. Type each table on a separate page and indicate by marginal notations its approximate piacement in the text. General footnotes should be marked as "Notes:" and a, b, c, etc., marked for specific footnotes. Asterisks ${ }^{*}$ or ** indicate significance at the 5-and 1-percent levels, respectively. If tables are typed on oversized paper, please submit the oversized paper in lieu of poorly reproduced reductions. The author should check tables to be sure that totals are correct and that the title, column headings, footnotes, etc., clearly explain the content of the table

Figures. Figures must be titled and numbered consecutively with Arabic numerals. Captions should present sufficient information to describe the purpose of the figure. Figures for accepted manuscripts must be of professional quality, ready for reproduction, executed on white paper in black ink, with clear, medium-weight black lines. All lettering on figures must be rendered by an artist in pen and ink, by means of dry transfer letters, or by applying typeset material to prepared artwork. Typewritten lettering will not be accepted. Figures generated by laser printer are acceptable.

Footnotes. Footnotes must be typed double-spaced and placed on separate sheets at the end of the manuscript. Footnotes must not be used for the purpose of citation. Footnotes with extensive content should be avoided.

References. All works cited in the text must be alphabetically arranged in a double-spaced list at the end of the manuscript. Examples:

Brown, S., and J. Warner. "Using Daily Stock Returns: The Case of Event Studies." Journal of Financial Economics, 14 (March 1985), 1-31.

Ross, S. A. "Return Risk and Arbitrage." In Risk and Return in Finance, Vol. I, I. Friend and J. L. Bicksler, eds. Cambridge, MA: Ballinger (1977). 